\title{
Hypoxia reduces ER-to-Golgi protein trafficking and increases cell death by inhibiting the adaptive unfolded protein response in mouse beta cells
}

\author{
Mohammed Bensellam ${ }^{1}$ • Emma L. Maxwell ${ }^{1}$. Jeng Yie Chan ${ }^{1}$. Jude Luzuriaga ${ }^{1}$. \\ Phillip K. West ${ }^{1}$ - Jean-Christophe Jonas ${ }^{2}$ - Jenny E. Gunton ${ }^{1,3,4}$ • D. Ross Laybutt ${ }^{1}$
}

Received: 26 October 2015 / Accepted: 16 March 2016/Published online: 4 April 2016

(C) Springer-Verlag Berlin Heidelberg 2016

\begin{abstract}
Aims/hypothesis Hypoxia may contribute to beta cell failure in type 2 diabetes and islet transplantation. The adaptive unfolded protein response (UPR) is required for endoplasmic reticulum (ER) homeostasis. Here we investigated whether or not hypoxia regulates the UPR in beta cells and the role the adaptive UPR plays during hypoxic stress.

Methods Mouse islets and MIN6 cells were exposed to various oxygen $\left(\mathrm{O}_{2}\right)$ tensions. DNA-damage inducible transcript 3 (DDIT3), hypoxia-inducible transcription factor (HIF) $1 \alpha$ and HSPA5 were knocked down using small interfering (si)RNA; $H s p a 5$ was also overexpressed. $d b / d b$ mice were used.

Results Hypoxia-response genes were upregulated in vivo in the islets of diabetic, but not prediabetic, $d b / d b$ mice. In isolated mouse islets and MIN6 cells, $\mathrm{O}_{2}$ deprivation (1-5\% vs $20 \%$; 4-24 h) markedly reduced the expression of adaptive UPR genes, including Hspa5, Hsp90b1, Fkbp11 and spliced Xbp1. Coatomer protein complex genes (Copa, Cope, Copg
\end{abstract}

Electronic supplementary material The online version of this article (doi:10.1007/s00125-016-3947-y) contains peer-reviewed but unedited supplementary material, which is available to authorised users.

D. Ross Laybutt

r.laybutt@garvan.org.au

1 Garvan Institute of Medical Research, St Vincent's Hospital, UNSW Australia, 384 Victoria Street, Darlinghurst, Sydney, NSW 2010, Australia

2 Université catholique de Louvain, Institut de recherche expérimentale et clinique, Pôle d'endocrinologie, diabète et nutrition, Brussels, Belgium

3 Westmead Hospital, Sydney, NSW, Australia

4 The Westmead Millennium Institute for Medical Research, The University of Sydney, Sydney, NSW, Australia [also known as Copg1], Copz1 and Copz2) and ER-to-Golgi protein trafficking were also reduced, whereas apoptotic genes (Ddit3, Atf3 and Trb3 [also known as Trib3]), c-Jun N-terminal kinase (JNK) phosphorylation and cell death were increased. Inhibition of JNK, but not HIF $1 \alpha$, restored adaptive UPR gene expression and ER-to-Golgi protein trafficking while protecting against apoptotic genes and cell death following hypoxia. DDIT3 knockdown delayed the loss of the adaptive UPR and partially protected against hypoxia-induced cell death. The latter response was prevented by HSPA5 knockdown. Finally, Hspa5 overexpression significantly protected against hypoxia-induced cell death.

Conclusions/interpretation Hypoxia inhibits the adaptive UPR in beta cells via JNK and DDIT3 activation, but independently of HIF $1 \alpha$. Downregulation of the adaptive UPR contributes to reduced ER-to-Golgi protein trafficking and increased beta cell death during hypoxic stress.

Keywords Apoptosis - Beta cell · Hypoxia - Islet of Langerhans · Protein trafficking · Type 2 diabetes $\cdot$ Unfolded protein response

$\begin{array}{ll}\text { Abbreviations } \\ \text { ATF } & \text { Activating transcription factor } \\ \text { Cop } & \text { Coatomer protein complex } \\ \text { DDIT3 } & \text { DNA-damage inducible transcript } 3 \\ \text { EGFP } & \text { Enhanced green fluorescent protein } \\ \text { EIF2A } & \text { Eukaryotic translation initiation factor } 2 \alpha \\ \text { ER } & \text { Endoplasmic reticulum } \\ \text { GFP } & \text { Green fluorescent protein } \\ \text { HIF } & \text { Hypoxia-inducible transcription factor } \\ \text { HSPA5 } & \text { Heat shock 70kDa protein 5 } \\ \text { HSP90B1 } & \text { Heat shock 90kDa protein beta } \\ \text { ISR } & \text { Integrated stress response }\end{array}$




$\begin{array}{ll}\text { JNK } & \text { c-Jun N-terminal kinase } \\ \text { JNKi } & \text { JNK inhibitor } \\ \text { PERK } & \text { PKR-like ER kinase } \\ \text { PKR } & \text { Double-stranded RNA-dependent protein kinase } \\ \mathrm{pO}_{2} & \text { Oxygen pressure } \\ \text { siRNA } & \text { Small interfering RNA } \\ \text { UPR } & \text { Unfolded protein response } \\ \text { VSVG } & \text { Vesicular stomatitis viral glycoprotein } \\ \text { XBP1 } & \text { X-box binding protein 1 }\end{array}$

\section{Introduction}

Chronic exposure to elevated glucose levels exerts toxic effects in beta cells, a concept known as glucotoxicity [1]. Glucotoxicity contributes to the deterioration of functional beta cell mass in type 2 diabetes. However, the precise mechanisms involved are not understood.

Hypoxia occurs when demand for oxygen exceeds supply leading to a drop in tissue oxygen pressure $\left(\mathrm{pO}_{2}\right)$. Beta cells are sensitive to hypoxic stress because their function depends heavily on the acceleration of mitochondrial metabolism upon glucose stimulation to generate ATP [2]. Glucose stimulation of beta cell oxygen consumption generates intracellular hypoxia leading to activation of hypoxia-inducible factors (HIFs) and upregulation of HIF-target genes in rodent and human islets (reviewed in [1]). The presence of hypoxia in vivo in the islets of animal models of type 2 diabetes [3-8] supports a role for hypoxic stress in beta cell apoptosis. Moreover, severe hypoxia in islet grafts contributes to beta cell apoptosis in the early post-transplantation period $[9,10]$. However, the mechanisms underlying the deleterious effects of hypoxia in beta cells are unclear.

The endoplasmic reticulum (ER) is highly active in beta cells due to heavy engagement in the synthesis, processing and secretion of insulin. This function relies on a finely tuned adaptive unfolded protein response (UPR) [11]. The accumulation of unfolded proteins (ER stress), occurring as a result of an imbalance between ER folding capacity and demand, triggers the UPR via three main sensors, namely double-stranded RNA-dependent protein kinase (PKR)-like ER kinase (PERK), inositol requiring kinase 1 (IRE1) and activating transcription factor (ATF) 6 . Activation of PERK and the ensuing phosphorylation of eukaryotic translation initiation factor 2 (EIF2A) leads to rapid and transient reduction in global protein synthesis to attenuate ER load. IRE1 triggers the unconventional splicing of $X b p 1$ mRNA generating X-box binding protein $1(\mathrm{XBP} 1 \mathrm{~s})$ transcription factor. XBP1s, together with ATF6, stimulates the expression of genes that enhance ER capacity as well as the degradation of unfolded proteins. However, irresolvable ER stress triggers apoptosis via several effectors including c-Jun N-terminal kinase (JNK), DNAdamage inducible transcript 3 (DDIT3; also known as
CHOP/GADD153), ATF3 and Tribbles homolog 3 (TRB3) [11-13]. Interestingly, recent studies suggest that a progressive decline in the adaptive UPR characterises beta cell failure in type 2 diabetes [14-16] as well as in islet transplantation [17]. Therefore, knowledge of the regulatory mechanisms controlling the adaptive UPR is crucial.

In the present study, we demonstrate for the first time that hypoxia downregulates the adaptive UPR specifically in beta cells. We show that inhibition of the adaptive UPR is associated with reduced ER-to-Golgi protein trafficking and beta cell death during hypoxic stress. Mechanistically, we show that hypoxia mediates these responses via JNK and DDIT3 activation, but independently of HIF $1 \alpha$. Our novel findings suggest that hypoxia may provide a cellular mechanism for failure of the adaptive UPR during the progressive loss of functional beta cell mass in type 2 diabetes.

\section{Methods}

Reagents Control Non-Targeting and ON-TARGETplus SMARTpool small interfering (si)RNAs and transfection reagent DharmaFECT3 were from Thermo Fisher Scientific (Lafayette, CO, USA). JNK inhibitor (JNKi) II SP600125 and NanoJuice transfection reagents were from Merck (Kilsyth, VIC, Australia).

Mice $\mathrm{C} 57 \mathrm{BL} / \mathrm{KsJ} d b / d b$ mice and their age-matched lean control mice $(\mathrm{C} 57 \mathrm{BL} / \mathrm{KsJ})$ were taken from the Garvan Institute breeding colony (Australian BioResources, Moss Vale, NSW, Australia), which was originally obtained from The Jackson Laboratory (BKS.Cg-Dock $7^{m}+/+\operatorname{Lepr}^{d b} / \mathrm{J}$; Bar Harbor, ME, USA). For islet culture [14], 8-10 week-old C57BL/6 J mice were taken from the Garvan Institute breeding colony, which was derived from The Jackson Laboratory colony that harbours an Nnt mutation. Islets were isolated as previously described [14]. Some experiments were performed on a subset of mice used in our previous study [14]. All experiments were approved by the Garvan Institute/ St. Vincent's Hospital Animal Experimentation Ethics Committee.

Cell culture and treatment MIN6 beta cells (P26-39) [18] and MEF cells were cultured in Dulbecco's modified Eagle's medium (Invitrogen, Carlsbad, CA, USA) containing $25 \mathrm{mmol} / 1$ glucose, $10 \mathrm{mmol} / \mathrm{l} \mathrm{HEPES}, 10 \% \mathrm{FCS}$ (vol./vol.), 50 units $/ \mathrm{ml}$ penicillin and $50 \mu \mathrm{g} / \mathrm{ml}$ streptomycin in the presence of normoxia $\left(20 \% \mathrm{O}_{2}\right)$ or hypoxia $\left(1 \% \mathrm{O}_{2}\right)$ using hypoxic chambers (Billups-Rothenberg, Del Mar, CA, USA). Cells were transfected with control, Ddit3, Hifla or Hspa5 siRNA. Enhanced green fluorescent protein (EGFP) or heat shock $70 \mathrm{kDa}$ protein 5 (HSPA5) expression vectors [18] were transfected into cells using NanoJuice transfection reagent. 
JNKi $(10 \mu \mathrm{mol} / \mathrm{l})$ was used to inhibit JNK activation. Cell death was determined with the use of a Cell Death Detection ELISA (Roche Diagnostics, Castle Hill, NSW, Australia) [19].

Real-time RT-PCR Real-time RT-PCR was performed as previously described [14]. Primer sequences are listed in Electronic Supplementary Material (ESM) Table 1. The value obtained for each specific gene product was normalised to the control gene cyclophilin A and expressed as a fold change of the value in control condition. Xbpl mRNA splicing measurement was performed as previously described [19].

Protein analysis Western blotting and immunostaining were performed as previously described $[7,20]$. Western blot bands were quantified by densitometry and normalised to total protein or loading control (actin, tubulin or 14-3-3). Antibodies are listed in ESM Table 2. For immunofluorescence experiments, images were acquired using Leica SP8 confocal microscope.

Trafficking assay ER-to-Golgi protein trafficking was assessed using the temperature-sensitive mutant vesicular stomatitis viral glycoprotein (VSVG) assay [21, 22]. MIN6 cells seeded on coverslips were transfected with VSVG protein tagged with green fluorescent protein (GFP). Cells were cultured in the presence of $20 \%$ or $1 \% \mathrm{O}_{2}$ for $24 \mathrm{~h}$ at $40^{\circ} \mathrm{C}$ to retain the VSVG in the ER. After addition of cycloheximide ( $20 \mu \mathrm{mol} / \mathrm{l})$ to prevent novel VSVG synthesis, trafficking was commenced by transfer to the permissive temperature of $32^{\circ} \mathrm{C}$. VSVG localisation was scored using confocal images according to the scale: 1, exclusively ER; 2, mostly ER with some Golgi; 3, equivalent ER and Golgi; 4, mostly Golgi with some ER; 5 exclusively Golgi [22].

Statistical analysis Results are means \pm SEM for the indicated number of experiments. Statistical significance was assessed by unpaired two-tailed Student's $t$ test, one-way ANOVA and a post test of Newman-Keuls or two-way ANOVA and a post test of Bonferroni.

\section{Results}

Hypoxia-response genes are upregulated in the islets of diabetic, but not in prediabetic, $\boldsymbol{d} \boldsymbol{b} / \boldsymbol{d} \boldsymbol{b}$ mice In $d b / d b$ mice, blood glucose levels were increased at 16 weeks (average blood glucose levels: control $8.1 \pm 0.5, n=9 ; d b / d b 26.0 \pm 1.8 \mathrm{mmol} / \mathrm{l}$, $n=7 ; p<0.001$ ) but not at 6 weeks of age (control $8.5 \pm 0.2$, $n=16$; $d b / d b 9.1 \pm 0.3 \mathrm{mmol} / \mathrm{l}, n=8$; not significant) compared with age-matched lean C57BL/KsJ control mice [14]. The mRNA levels of hypoxia-response genes Adm, Tpil, Gapdh and Enol were markedly upregulated in vivo in the islets of diabetic $d b / d b$ mice in comparison with age-matched control mice (Fig. 1a-d). In contrast, there were no significant changes in hypoxia-response genes in the islets of prediabetic $d b / d b$ mice (Fig. 1a-d). We have previously demonstrated the timedependent downregulation of UPR genes is important for adaptation to ER stress in the islets of diabetic $d b / d b$ mice [14]. Taken together, our studies demonstrate a novel in vivo association between islet hypoxia and the failure of the adaptive UPR in diabetic mice.

Hypoxia inhibits adaptive UPR gene expression in beta cells MIN6 cells were treated with normoxia $\left(20 \% \mathrm{O}_{2}\right)$ or hypoxia $\left(1 \% \mathrm{O}_{2}\right)$ for $24 \mathrm{~h}$. Hypoxia markedly reduced $\mathrm{Xbpl}$ mRNA splicing as well as the mRNA levels of adaptive UPR genes, including chaperones Hspa5 (Bip) and Hsp90b1 (Grp94) and the peptidyl prolyl isomerase Fkbp11 (Table 1). In contrast, hypoxia strongly upregulated the mRNA levels of apoptotic genes Ddit3, Atf3 and Trb3 (Table 1). As expected, hypoxia strongly upregulated the mRNA levels of HIF-target genes Adm, Aldoa, Hmoxl and Tpil (Table 1). In agreement with these findings, hypoxia reduced the protein levels of XBP1s by more than $90 \%$, whereas phosphorylated IRE1A was unchanged (Fig. 2a, b). In addition, the protein levels of full-length and cleaved ATF 6 were reduced by about $20 \%$ and $50 \%$, respectively (Fig. 2a, b). Furthermore, the protein levels of HSPA5 and heat shock $90 \mathrm{kDa}$ protein beta (HSP90B1) were reduced by more than $50 \%$ and $70 \%$, respectively (Fig. 2a, b). Moreover, hypoxia significantly reduced PERK phosphorylation, whereas EIF2A phosphorylation was
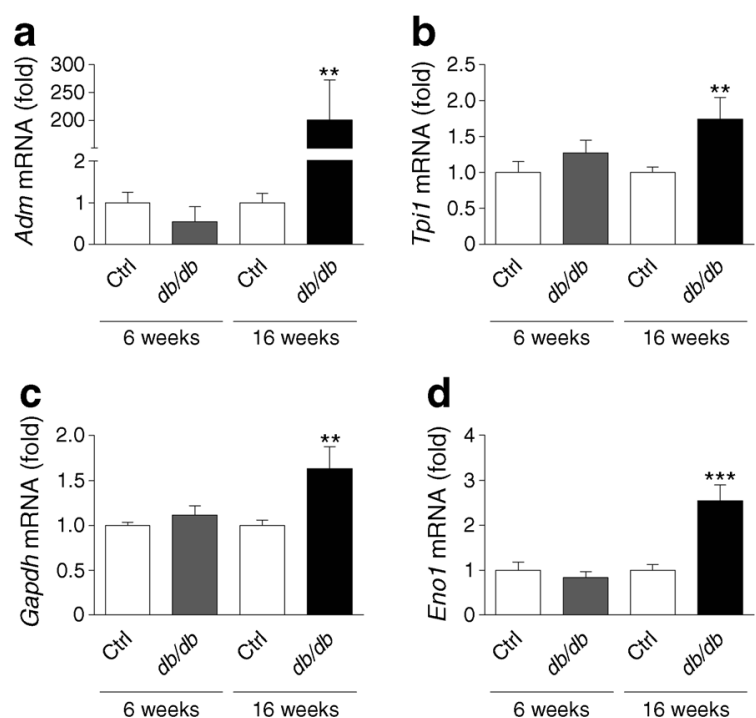

Fig. 1 HIF-target gene mRNA levels are upregulated in the islets of diabetic, but not prediabetic, $d b / d b$ mice. Changes in the mRNA levels of Adm, Tpil, Gapdh and Enol (a-d) in the islets of control C57BL/KsJ (Ctrl, white bars, 6 and 16 weeks of age), prediabetic $d b / d b$ (grey bars, 6 weeks of age) and diabetic $d b / d b$ (black bars, 16 weeks of age) mice. $n=8-14$ animals per group. ${ }^{* *} p<0.01, * * * p<0.001$ vs control at the same age 
Table 1 Hypoxia reduced the mRNA levels of adaptive UPR genes in MIN6 cells ${ }^{\mathrm{a}}$

\begin{tabular}{lll}
\hline mRNA level $^{\mathrm{b}}$ & Normoxia & Hypoxia \\
\hline HIF-target genes & & \\
$\quad$ Adm & $1.0 \pm 0.30$ & $119.5 \pm 34.2^{*}$ \\
Aldoa & $1.0 \pm 0.07$ & $6.92 \pm 0.59^{* * *}$ \\
Tpil & $1.0 \pm 0.10$ & $6.39 \pm 0.09^{* * *}$ \\
Hmox1 & $1.0 \pm 0.09$ & $5.07 \pm 1.39^{*}$ \\
Adaptive UPR genes & & \\
Xbp1s/t & & \\
Hspa5 (Bip) & $0.47 \pm 0.01$ & $0.31 \pm 0.02^{* * *}$ \\
Hsp90b1 (Grp94) & $1.0 \pm 0.07$ & $0.67 \pm 0.06^{*}$ \\
Fkbp11 & $1.0 \pm 0.06$ & $0.53 \pm 0.02^{* * *}$ \\
Apoptotic genes & $1.0 \pm 0.06$ & $0.17 \pm 0.01 * * *$ \\
Ddit3 (Chop) & & \\
Atf3 & $1.0 \pm 0.21$ & $17.85 \pm 4.42^{* *}$ \\
Trb3 & $1.0 \pm 0.17$ & $10.36 \pm 3.16^{*}$ \\
\hline
\end{tabular}

Data are mean \pm SEM from four independent experiments

${ }^{a}$ MIN6 cells were cultured in the presence of normoxia $\left(20 \% \mathrm{O}_{2}\right)$ or hypoxia $\left(1 \% \mathrm{O}_{2}\right)$ for $24 \mathrm{~h}$

${ }^{b}$ mRNA levels are expressed as fold change of the level in control (normoxia)

${ }^{\mathrm{c}} \mathrm{Xbp} 1 \mathrm{mRNA}$ splicing is expressed as the ratio of spliced over total mRNA

Unpaired two-tailed Student's $t$ test; ${ }^{*} p<0.05,{ }^{* *} p<0.01,{ }^{* * *} p<0.001$ vs normoxia

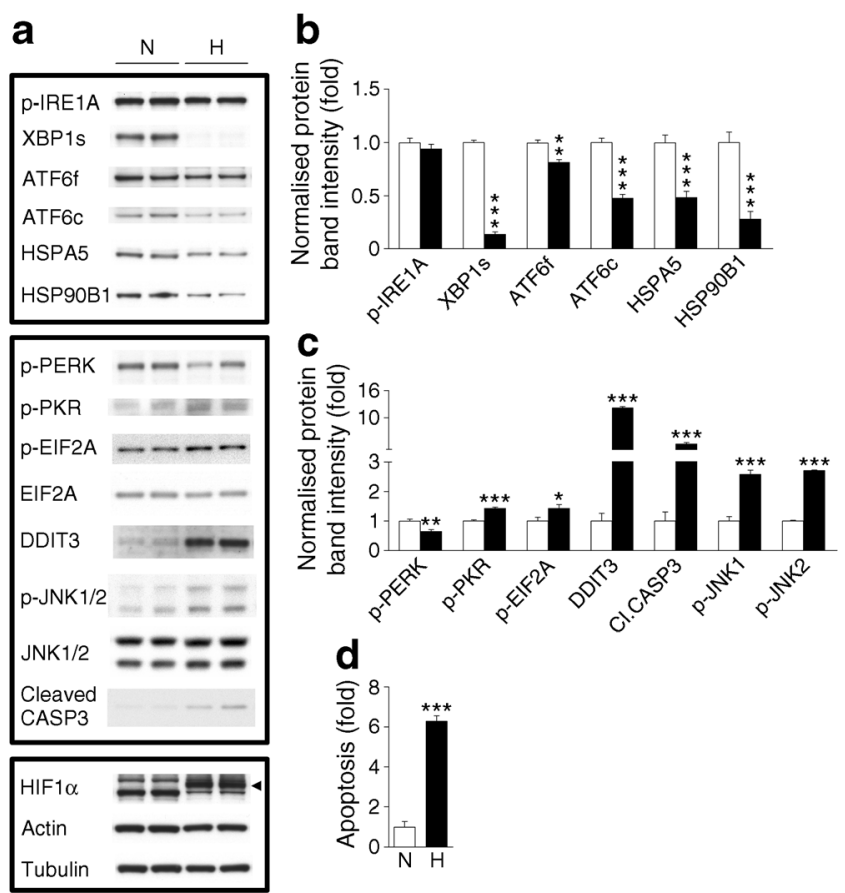

Fig. 2 Hypoxia decreases adaptive UPR protein expression and upregulates pro-apoptotic protein expression and apoptosis. MIN6 cells were cultured for $24 \mathrm{~h}$ in the presence of normoxia $\left(\mathrm{N}, 20 \% \mathrm{O}_{2}\right.$, white bars) or hypoxia $\left(\mathrm{H}, 1 \% \mathrm{O}_{2}\right.$, black bars). Changes in (a-c) protein levels and (d) apoptosis. $n=3-5$ experiments. ${ }^{*} p<0.05, * * p<0.01$, $* * * p<0.001$ vs normoxia. Cl., cleaved increased (Fig. 2a, c) suggesting possible activation of the integrated stress response (ISR) and an upstream EIF2A kinase other than PERK [23]. We therefore checked phosphorylation of PKR and found it was increased by hypoxia (Fig. 2a, c). Finally, hypoxia markedly increased proapoptotic effectors including DDIT3 and cleaved caspase 3 protein levels and JNK $1 / 2$ phosphorylation in association with increased cell death (Fig. 2a, c and d).

The effects of hypoxia on the adaptive UPR were confirmed in isolated primary mouse islets. Hypoxia $\left(1 \% \mathrm{O}_{2}\right.$ for 12 h) significantly downregulated $F k b p 11$, the chaperone Dnajc3 $\left(p 58^{I P K}\right)$ and the co-chaperone Dnajb9, and tended to reduce $H$ spa 5 and the protein disulfide isomerase Pdia4 (Erp72) (Table 2). In contrast, hypoxia strongly upregulated the mRNA levels of apoptotic genes Ddit3, Atf3 and Trb3 as well as HIF-target genes in mouse islets (Table 2). Analysis of dispersed mouse islets exposed to hypoxia for $24 \mathrm{~h}$ revealed a marked downregulation of KDEL-containing ER proteins in beta cells (Fig. 3). The anti-KDEL antibody detects HSPA5, HSP90B1 and protein disulfide isomerase associated 6 (ESM Fig. 1).

To assess whether the effects of hypoxia on the UPR in beta cells were cell-specific, we performed studies using MEF cells (exposed to $20 \%$ or $1 \% \mathrm{O}_{2}$ for $24 \mathrm{~h}$ ). We found that, in opposition to findings in beta cells, hypoxia significantly increased

Table 2 Hypoxia reduced the mRNA levels of adaptive UPR genes in mouse islets ${ }^{\mathrm{a}}$

\begin{tabular}{lll}
\hline mRNA level $^{\mathrm{b}}$ & Normoxia & Hypoxia \\
\hline HIF-target genes & & \\
$\quad$ Adm & $1.0 \pm 0.63$ & $44.5 \pm 3.04^{* * *}$ \\
$\quad$ Aldoa & $1.0 \pm 0.31$ & $4.03 \pm 0.47^{* *}$ \\
Tpi1 & $1.0 \pm 0.16$ & $8.24 \pm 0.89^{* *}$ \\
Hmox1 & $1.0 \pm 0.36$ & $26.0 \pm 2.93^{* *}$ \\
Adaptive UPR genes & & \\
Hspa5 (Bip) & $1.0 \pm 0.16$ & $0.76 \pm 0.08$ \\
Fkbp11 & $1.0 \pm 0.03$ & $0.55 \pm 0.02^{* * *}$ \\
Pdia4 (Erp72) & $1.0 \pm 0.23$ & $0.64 \pm 0.08$ \\
Dnajc3 (p58 IPK $^{\text {Dif }}$ & $1.0 \pm 0.08$ & $0.64 \pm 0.01^{*}$ \\
Dnajb9 & $1.0 \pm 0.12$ & $0.56 \pm 0.03^{*}$ \\
Apoptotic genes & & \\
Ddit3 (Chop) & $1.0 \pm 0.08$ & $8.80 \pm 1.93^{*}$ \\
Atf3 & $1.0 \pm 0.12$ & $4.93 \pm 0.91^{*}$ \\
Trb3 & $1.0 \pm 0.07$ & $2.32 \pm 0.30^{*}$ \\
\hline
\end{tabular}

Data are means \pm SEM from three independent experiments

${ }^{\mathrm{a}}$ Isolated mouse islets were cultured in the presence of normoxia $(20 \%$ $\left.\mathrm{O}_{2}\right)$ or hypoxia $\left(1 \% \mathrm{O}_{2}\right)$ for $12 \mathrm{~h}$

${ }^{\mathrm{b}}$ mRNA levels are expressed as fold change of the level in control (normoxia)

Unpaired two-tailed Student's $t$ test; ${ }^{*} p<0.05,{ }^{* *} p<0.01,{ }^{* * *} p<0.001$ vs normoxia 

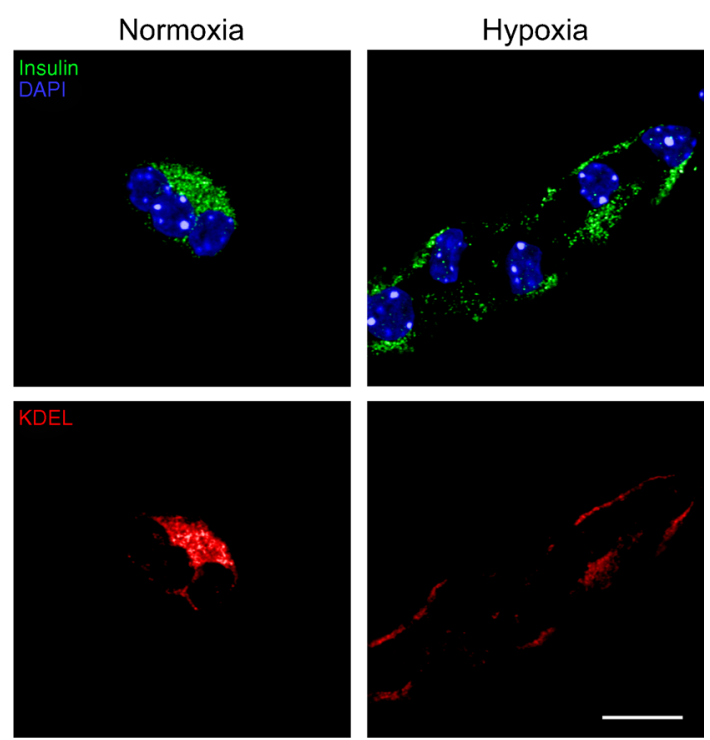

Fig. 3 Hypoxia decreases KDEL-containing ER proteins in primary beta cells. Immunostaining of KDEL in dispersed mouse islets cultured for $24 \mathrm{~h}$ in the presence of normoxia $\left(20 \% \mathrm{O}_{2}\right)$ or hypoxia $\left(1 \% \mathrm{O}_{2}\right)$. Images are representative of three experiments. Scale bar, $10 \mu \mathrm{m}$

the mRNA levels of adaptive UPR genes Hspa5, Hsp90b1, Fkbp11 and Pdia 4 in MEF cells (ESM Fig. 2b). Apoptotic and HIF-target genes were also increased (ESM Fig. 2a,c). These findings suggest that hypoxia activates canonical ER stress response pathways in MEF cells and that its inhibitory effects on the adaptive UPR are specific in beta cells.

\section{Hypoxia time-dependently inhibits the adaptive UPR} without transient activation in beta cells Hypoxia timedependently decreased the mRNA levels of adaptive UPR genes without detection of transient activation (Fig. 4a-d). On the other hand, hypoxia time-dependently increased the mRNA levels of Ddit3 (Fig. 4e). In association with the changes in the adaptive UPR, XBP1 protein levels were strongly and rapidly reduced (Fig. 4f, ESM Fig. 3). ATF6c protein levels were also downregulated with time (Fig. 4f, ESM Fig. 3), whereas EIF2A phosphorylation and cleaved caspase 3 and DDIT3 protein levels were progressively increased (Fig. 4f, ESM Fig. 3).

\section{Hypoxia reduces coatomer complex gene expression and} ER-to-Golgi protein trafficking UPR coordination of the secretory pathway and ER-to-Golgi vesicular transport is fundamental in professional secretory cells $[24,25]$. In parallel with the attenuation of the adaptive UPR, hypoxia $\left(1 \% \mathrm{O}_{2}\right)$ reduced the mRNA levels of coatomer complex genes Copa, Cope, Copg [also known as Copg1], Copz1 and Copz2 in MIN6 cells and mouse islets (Fig. 5a, b). We also tested whether hypoxia alters ER-to-Golgi protein trafficking using a VSVG reporter assay [26]. The temperature-sensitive VSVG mutant protein is retained in the $\mathrm{ER}$ at $40^{\circ} \mathrm{C}$ (ESM Fig. 4) and translocates to the Golgi after the switch to the
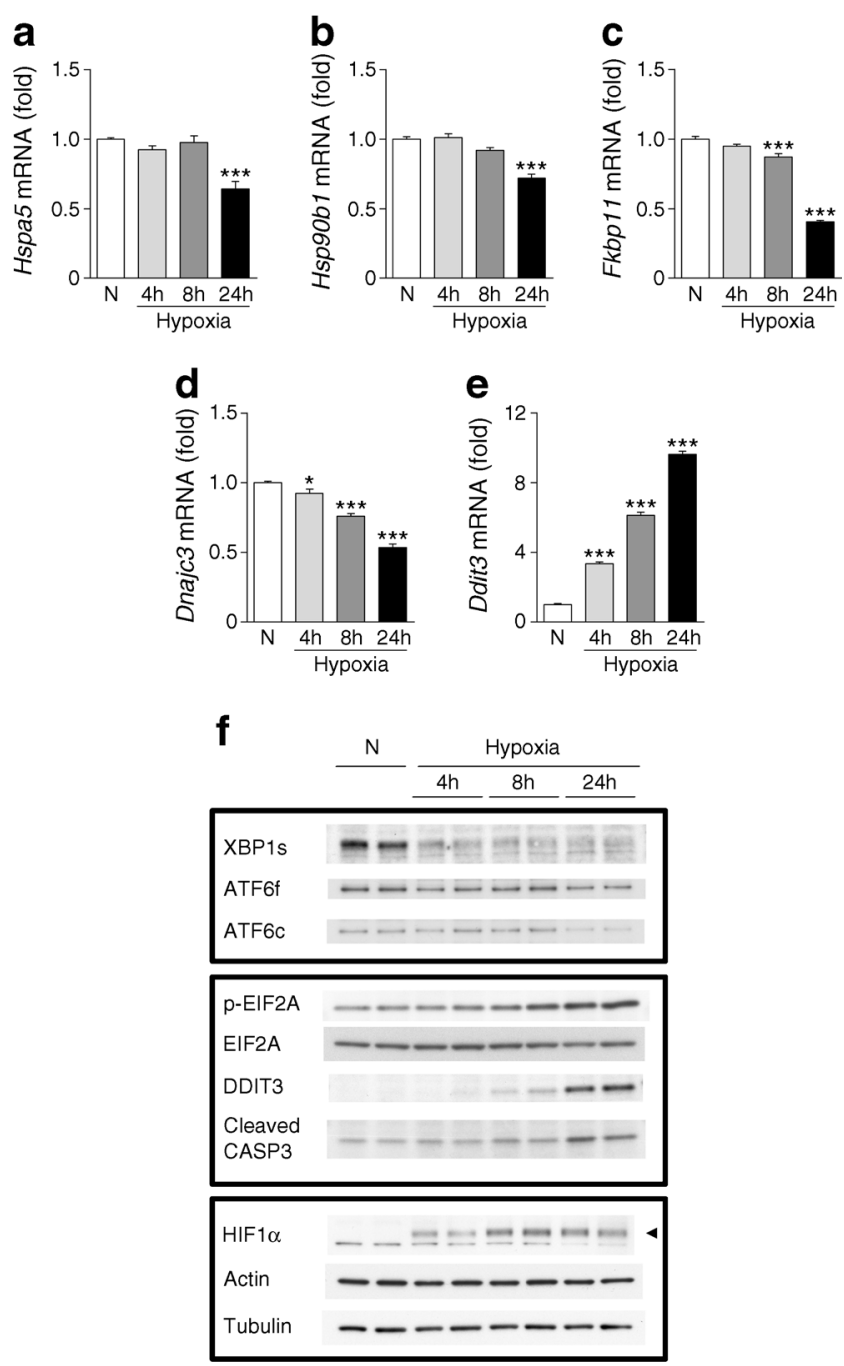

Fig. 4 Hypoxia time-dependently decreases adaptive UPR gene expression without transient activation, while increasing apoptotic gene expression. MIN6 cells were cultured for 4-24 h in the presence of normoxia $(\mathrm{N}$, $\left.20 \% \mathrm{O}_{2}\right)$ or hypoxia $\left(1 \% \mathrm{O}_{2}\right)$. Changes in (a-e) mRNA and (f) protein levels. $n=4$ experiments. ${ }^{*} p<0.05$, ${ }^{* * *} p<0.001$ vs normoxia

permissive temperature of $32^{\circ} \mathrm{C}$ [21]. Interestingly, in comparison to the normoxic condition, cells treated with hypoxia $(1 \%$ $\mathrm{O}_{2}$ ) retained substantial VSVG in the ER (Fig. 5c, d), thereby demonstrating that hypoxia delays ER-to-Golgi protein trafficking. ER morphology did not differ in cells treated with normoxia and hypoxia (ESM Fig. 5). The positive control ER stress inducer, tunicamycin, strongly inhibited ER-toGolgi trafficking of VSVG (Fig. $5 \mathrm{c}$, d). These results demonstrate for the first time that hypoxia impairs ER-to-Golgi protein trafficking in beta cells in association with the downregulation of adaptive UPR and coatomer protein complex (Cop) genes. Similar results were obtained using $5 \% \mathrm{O}_{2}$ (ESM Figs 6,7), whereas with $10 \% \mathrm{O}_{2}$, hypoxia-response gene and Ddit3 mRNA levels were only slightly increased and the majority of the adaptive UPR and Cop genes were unchanged, 


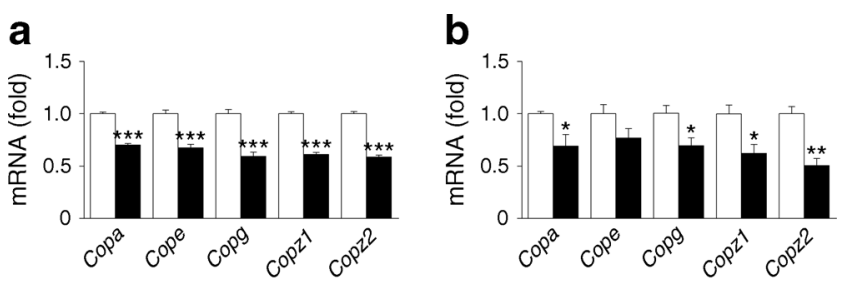

C
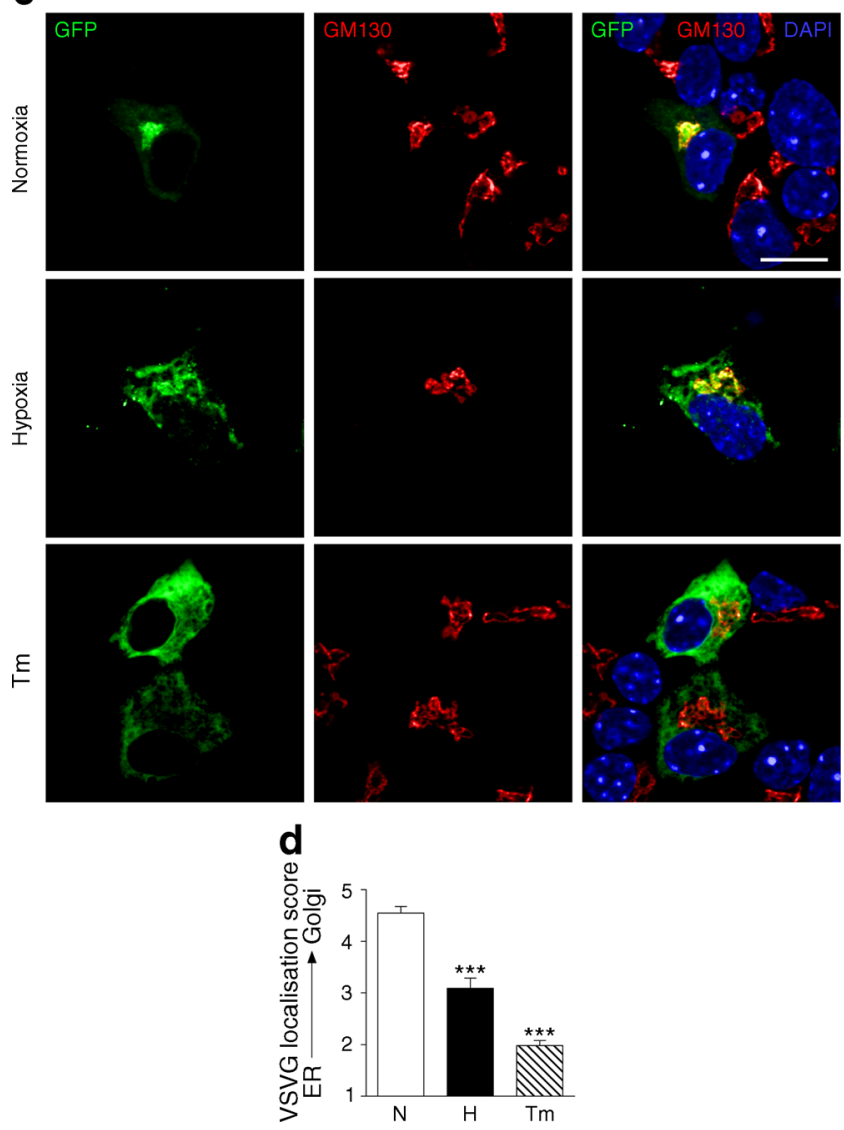

Fig. 5 Hypoxia reduces Cop gene expression and delays ER-to-Golgi protein trafficking. (a, c, d) MIN6 cells and (b) mouse islets were cultured in the presence of normoxia $\left(\mathrm{N}, 20 \% \mathrm{O}_{2}\right.$, white bars) or hypoxia $(\mathrm{H}, 1 \%$ $\mathrm{O}_{2}$, black bars). (a, b) Changes in Cop gene mRNA levels. (c) Representative images of VSVG-GFP and Golgi marker GM130 at $32^{\circ} \mathrm{C}$. Tm: tunicamycin treatment $\left(5 \mu \mathrm{g} / \mathrm{ml} ; 20 \% \mathrm{O}_{2}\right)$. Scale bar, $10 \mu \mathrm{m}$. (d) VSVG localisation score. $n=3-4$ experiments. ${ }^{*} p<0.05$, $* * p<0.01, * * * p<0.001$ vs normoxia

with the exception of slightly reduced Copzl mRNA levels (ESM Figs 8, 9).

Hypoxia downregulates the adaptive UPR independently of HIF $1 \alpha$ activation Hypoxia triggers a transcriptional programme including gene repression via the stabilisation of HIF $1 / 2 \alpha[27,28]$. We therefore examined the role of HIF $1 \alpha$ in hypoxia-mediated downregulation of adaptive UPR. Knockdown of HIF1 $\alpha$ using siRNA prevented the upregulation of HIF-target genes after hypoxia (ESM Fig. 10a-d), but did not affect hypoxia-mediated downregulation of adaptive UPR genes Hspa5, Hsp90b1, Fkbpll and Pdia4 (ESM
Fig. $10 \mathrm{e}-\mathrm{h})$. On the other hand, HIF1 $\alpha$ knockdown potentiated the hypoxia-mediated increases in Ddit $3, A t f 3$ and Trb3 mRNA levels and cell death (ESM Fig. 10i-1). These results show that Hifl $\alpha$ activation is not required for the decline of adaptive UPR gene expression during hypoxia.

JNK activity is partially responsible for downregulation of the adaptive UPR, reduced ER-to-Golgi trafficking and increased beta cell death following hypoxia JNK has been implicated in beta cell apoptosis under various stress conditions [19, 29-34], but has not previously been investigated in the context of islet hypoxia. Here we tested whether JNK activity influences beta cell responses to hypoxia. Strikingly, treatment of MIN6 cells with JNKi completely protected against the hypoxia-mediated reductions in Hspa5 and Hsp $90 b 1$ mRNA levels, and partially restored Fkbp 11 and Dnajc3 mRNA levels (Fig. 6a-d). In agreement, inhibition of JNK activity prevented the hypoxia-mediated reduction of KDEL immunostaining (Fig. 6e). These changes were accompanied by the partial normalisation of XBP1s, PKR and EIF2A phosphorylation, DDIT3 and cleaved caspase 3 protein levels (Fig. 6f, ESM Fig. 11) as well as reduced cell death (Fig. 6g). Additionally, JNK inhibition either partially or completely protected against hypoxia-mediated reductions in Cop mRNA levels (Fig. 6h-k) and ER-to-Golgi protein trafficking (Fig. 61, m). These novel findings indicate that JNK activation is necessary for alterations in the UPR during hypoxic stress.

DDIT3 induction is required for hypoxia-mediated downregulation of the adaptive UPR Since DDIT3 can act as a negative transcriptional regulator $[35,36]$ and its expression was lowered by JNK inhibition (Fig. 6f), we examined the influence of DDIT3 in the hypoxia-mediated changes in the adaptive UPR. Interestingly, siRNA-mediated knockdown of DDIT3 expression (Fig. 7a, ESM Fig. 12) upregulated the mRNA levels of adaptive UPR genes Hspa5, Hsp90b1 and Fkbp11 under normoxia and delayed their downregulation following hypoxia (Fig. 7b-d). This was associated with a partial reduction in hypoxia-induced cell death (Fig. 7e). We then tested whether the protective effect of DDIT3 knockdown on hypoxia-induced cell death was due to changes in the adaptive UPR using knockdown of both DDIT3 and HSPA5. We found that the protective effect of DDIT3 knockdown was abolished with the concomitant knockdown of HSPA5. These findings demonstrate that downregulation of the adaptive UPR is required for DDIT3-dependent cell death during hypoxia (Fig. 7e).

Overexpression of HSPA5 significantly protects against hypoxia-induced beta cell death To further confirm the role of adaptive UPR downregulation in hypoxia-induced beta cell death, we examined the effects of restoring expression of the 
Fig. 6 JNK inhibition protects against downregulation of adaptive UPR and Cop gene expression, defective ER-toGolgi protein trafficking and apoptosis due to hypoxia. MIN6 cells were cultured under normoxia $\left(20 \% \mathrm{O}_{2}\right.$, white bars) or hypoxia $\left(1 \% \mathrm{O}_{2}\right.$, black bars) in the presence of DMSO $(\mathrm{C}$, control) or JNKi $(10 \mu \mathrm{mol} / \mathrm{l})$. Changes in (a-d) adaptive UPR gene expression, (e) KDEL immunostaining, (f) protein levels, (g) apoptosis, (h-k) Cop gene expression, (l) VSVG-GFP subcellular localisation at $32^{\circ} \mathrm{C}$ and (m) VSVG localisation score.

Scale bars, $10 \mu \mathrm{m} . n=3-5$ experiments. $* p<0.05$,

$* * p<0.01, * * * p<0.001 \mathrm{vs}$ normoxia. ${ }^{\dagger} p<0.05,{ }^{\dagger \dagger} p<0.01$, ${ }^{\dagger \dagger} p<0.001$ vs control

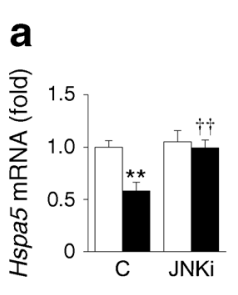

e

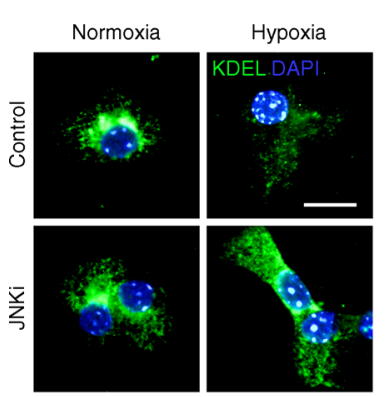

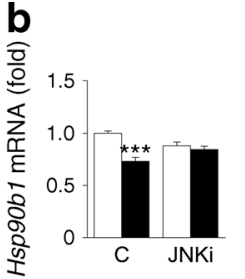

f

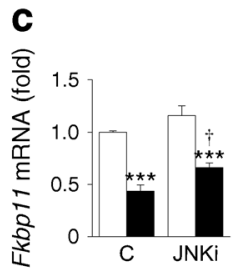

$f$
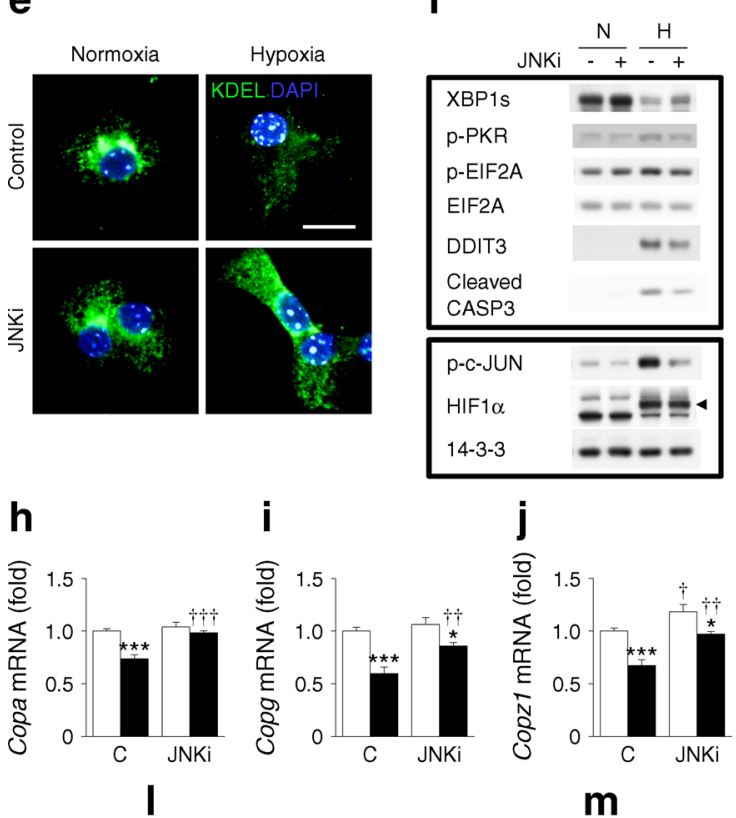

I

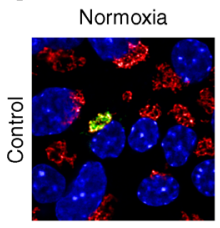

4 i

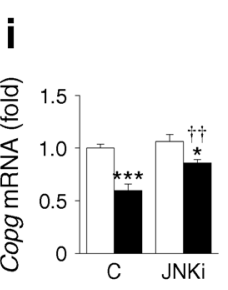

Hypoxia
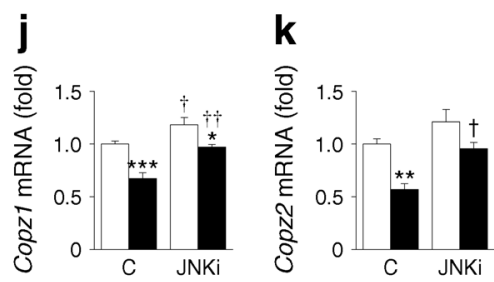

m

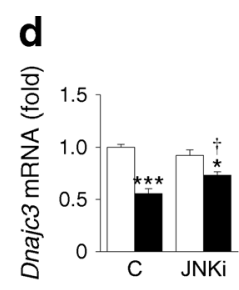

g
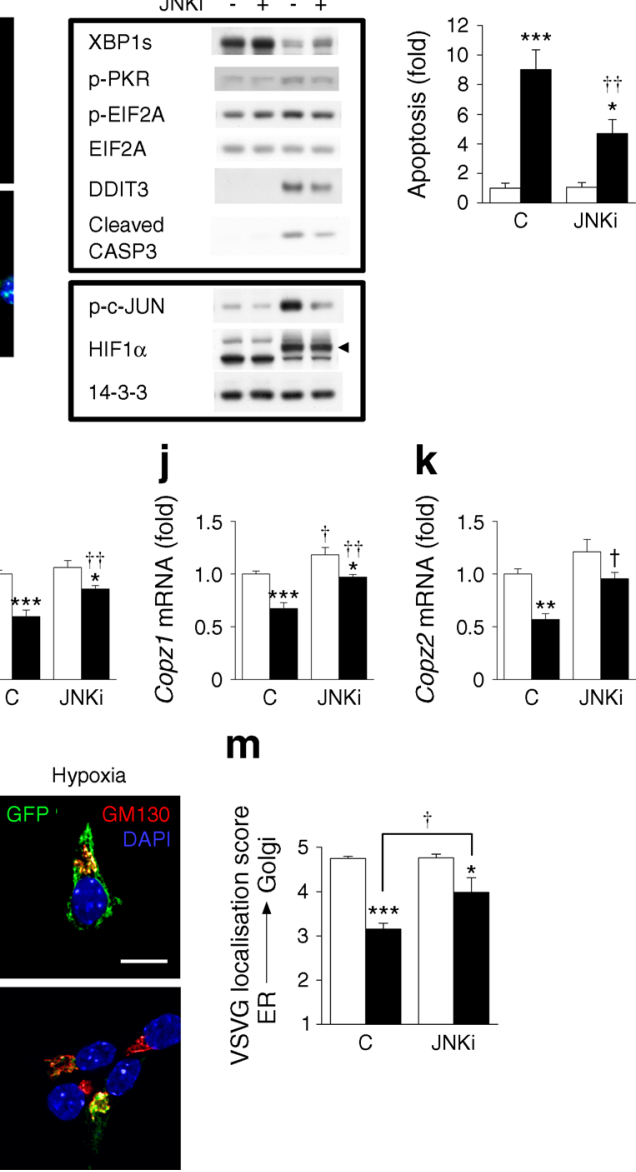

ER chaperone HSPA5 during hypoxia. Hspa 5 overexpression (Fig. 8a, b) did not affect the expression of adaptive UPR components Hsp90b1 or Fkbpl1 (Fig. 8c, d), but downregulated DDIT3 after hypoxia (Fig. 8a, e). Hypoxia-induced apoptosis was significantly reduced in HSPA5-overproducing vs control (EGFP-producing) MIN6 cells (Fig. 8f). These data are the first indication that the decline of the adaptive UPR is at least partially required for hypoxia-induced cell death in beta cells.

\section{Discussion}

We demonstrate here that hypoxia strongly downregulates the protective adaptive UPR in beta cells. We further show that downregulation of the adaptive UPR is associated with

impaired ER-to-Golgi protein trafficking and increased beta cell death during hypoxic stress. These findings indicate for the first time that hypoxia may contribute to the decline of the adaptive UPR in type 2 diabetes islets [14-16] and in islet graft failure [17]. Furthermore, our results provide JNK and DDIT3 activation as molecular mechanisms for downregulation of the adaptive UPR during hypoxic stress.

Aberrant UPR in beta cells during hypoxia Hypoxia may contribute to beta cell dedifferentiation and loss in type 2 diabetes [7, 37] and after islet transplantation [9]. In the present study, we demonstrate a novel in vivo association between hypoxia and downregulation of the adaptive UPR in islets of diabetic mice. The upregulation of hypoxia-response genes solely in the islets of diabetic mice (Fig. 1) is paralleled by reduced expression of a group of adaptive UPR genes (Hspa5, 

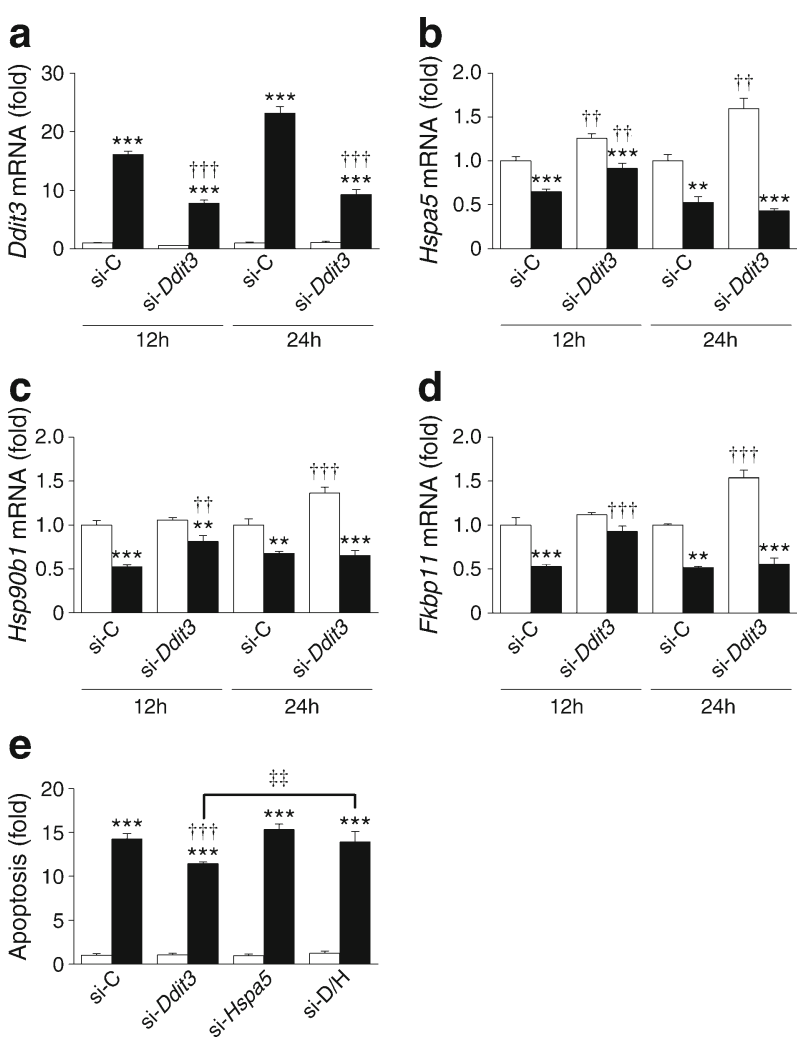

Fig. 7 DDIT3 contributes to hypoxia-induced apoptosis by downregulating the adaptive UPR. MIN6 cells transfected with either control siRNA (si-C) or siRNA against Ddit3, Hspa 5 or both $(\mathrm{si}-\mathrm{D} / \mathrm{H})$ were cultured for $12-24 \mathrm{~h}$ in the presence of normoxia $\left(20 \% \mathrm{O}_{2}\right.$; white bars) or hypoxia $\left(1 \% \mathrm{O}_{2}\right.$; black bars). Changes in (a-d) mRNA levels and (e) apoptosis. $n=3-7$ experiments. ${ }^{* *} p<0.01,{ }^{* * *} p<0.001$ vs normoxia. ${ }^{\dagger \dagger} p<0.01,{ }^{\dagger \dagger} p<0.001$ vs control siRNA. ${ }^{\dagger} p<0.01$ vs Ddit3 siRNA

Hsp90b1, Pdia4 and Dnajc3; averaged mRNA levels were reduced by $39.2 \pm 9.0 \%$ in the islets of diabetic compared with prediabetic $d b / d b$ mice, $n=8-12, p<0.01$ [14]). Our findings suggest that the deleterious effects of islet hypoxia include downregulation of the adaptive UPR in type 2 diabetes. In non-beta cells (ESM Fig. 2 and [38-40]), hypoxia activates canonical UPR signalling, including increased PERK/EIF2A phosphorylation, $X b p 1 \mathrm{mRNA}$ splicing and upregulation of ER chaperones. The atypical response to hypoxia in beta cells is evidenced by the absence of even transient activation of the adaptive UPR. Perhaps this is the result of an already high basal activity of the adaptive UPR in specialised secretory beta cells in comparison to non-secretory cells. Interestingly, despite the reduction of PERK phosphorylation, PKR and EIF2A phosphorylation and DDIT3 expression were increased (Figs 2 and 4), suggesting that hypoxia activates the ISR [23, 41, 42] (Fig. 8g).

\section{Hypoxia impairs ER-to-Golgi protein trafficking in beta} cells The ER is the primary compartment of the secretory pathway. After proper folding and post-translational modifications, cargo proteins undergo subsequent trafficking
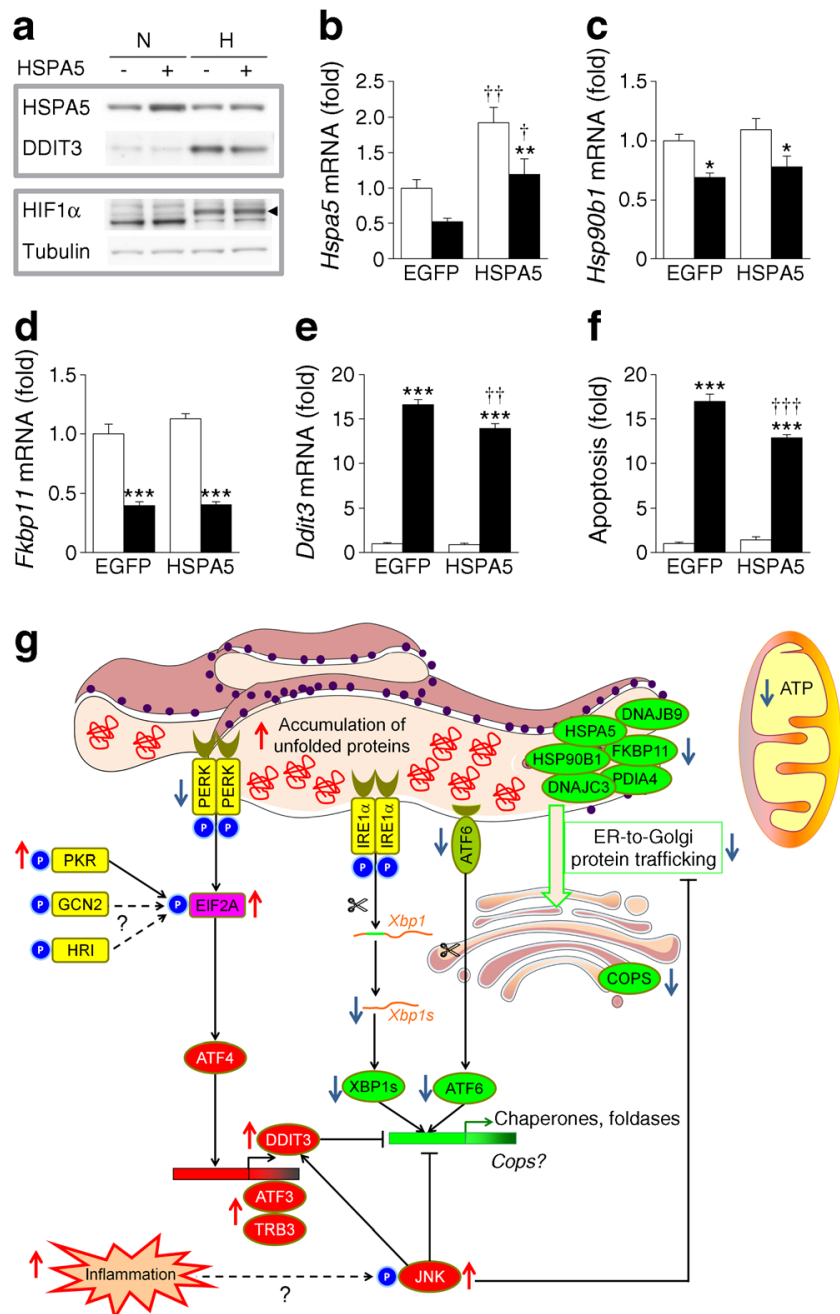

Fig. 8 Overexpression of Hspa5 partially protects against hypoxia-induced apoptosis. MIN6 cells transfected with either EGFP or HSPA5 encoding vector were cultured for $24 \mathrm{~h}$ in the presence of normoxia $\left(20 \% \mathrm{O}_{2}\right.$; white bars) or hypoxia $\left(1 \% \mathrm{O}_{2}\right.$; black bars). Changes in (a) protein, (b-e) mRNA levels and (f) apoptosis. $n=3-4$ experiments. ${ }^{*} p<0.05,{ }^{* *} p<0.01,{ }^{* * *} p<0.001$ vs normoxia. ${ }^{\dagger} p<0.05,{ }^{\dagger \dagger} p<0.01$, ${ }^{+1 \dagger} p<0.001$ vs control siRNA. (g) The proposed model: Hypoxia inhibits adaptive UPR gene expression and ER-to-Golgi protein trafficking in beta cells via the activation of JNK and DDIT3. Hypoxia-mediated reductions in ER folding capacity, ATP production and ER-to-Golgi protein trafficking lead to the accumulation of unfolded proteins, irresolvable ER stress and ultimately beta cell death. Direction of arrows indicates the effect of hypoxia. DNAJB9, DnaJ (Hsp40) homologue, subfamily B, member 9; DNAJC3, DnaJ (Hsp40) homologue, subfamily C, member 3; FKBP11, FK506 binding protein 11; GCN2, general control nonderepressible 2 (also known as EIF2AK4); HRI, heme regulated initiation factor 2 alpha kinase (also known as EIF2AK1); PDIA4, protein disulfide isomerase family $\mathrm{A}$, member 4

between the ER-Golgi compartments to receive additional modifications before vesicular transport to the plasma membrane and secretion. Our results clearly demonstrate that hypoxia slowed ER-to-Golgi protein trafficking. Whether defective trafficking is up or downstream of ER stress is not clear. The downregulation of chaperones, co-chaperones and foldases may exacerbate the accumulation of misfolded 
proteins in the ER leading to reduced ER-to-Golgi trafficking (Fig. 8g). Indeed, tunicamycin, which directly induces ER stress by inhibiting protein glycosylation, was sufficient to cause strong inhibition of ER-to-Golgi trafficking (Fig. 5). Alternatively, under hypoxic conditions, low cellular energetic status or reduced expression of ER-Golgi vesicle transport genes may initiate the trafficking defect, which in turn exacerbates ER stress because of the build-up of protein in the ER lumen (Fig. 8g). Interestingly, hypoxia reduced the mRNA levels of Cop genes (Fig. 5), several of which were also reduced in the islets of diabetic $d b / d b$ mice (ESM Fig. 13). These genes are regulated by XBP1s $[24,25]$ and are correlated with $X b p 1$ mRNA splicing following glucose stimulation in beta cells [43]. A recent study showed that impaired Golgi-to-ER retrograde transport can induce beta cell ER stress [44]. Moreover, blockage of ER-to-Golgi protein trafficking causes accumulation of proteins in the ER and thus ER stress in beta cells chronically exposed to saturated fatty acids $[21,22,45]$.

\section{Downregulation of the adaptive UPR links JNK-DDIT3} activation with beta cell apoptosis during hypoxic stress We have identified JNK as a crucial regulator of the UPR and beta cell survival during hypoxia. JNK activation reduces the adaptive UPR, Cop gene expression and ER-to-Golgi trafficking while promoting beta cell apoptosis following hypoxia (Fig. 6). We further show that JNK activation contributes to the downregulation of Cop gene expression in the islets of diabetic $d b / d b$ mice (ESM Fig. 13). Although JNKi is regarded as a specific inhibitor of JNK activation, we cannot rule out the potential of an off target effect. JNK is a wellestablished stress-activated pro-apoptotic effector in beta cells [29-34]. It also plays a role in the regulation of the UPR following pro-inflammatory cytokine stimulation $[19,46]$. Hypoxia-induced JNK activation appears to occur independently of IRE1 (Fig. 2). Interestingly, hypoxia increased the expression of inflammatory genes (ESM Fig. 14), raising the possibility that hypoxia activates JNK via inflammatory signalling. Moreover, ISR components (PKR and EIF2A phosphorylation and DDIT3 expression) were reduced by JNK inhibition during hypoxia (Fig. 6). DDIT3 is an established modulator of beta cell apoptosis [47], including that induced by hypoxia (Fig. 7 and $[8,37]$ ), an effect that we show was dependent on the decline of adaptive UPR (Fig. 7). HSPA5 overexpression only partially protects against the induction of Ddit3 and apoptosis during hypoxia (Fig. 8). However, other ER chaperones and protein folding enzymes are downregulated during hypoxia, which may reduce the impact of these factors when addressed individually.

Thus, our results identify a crucial role of DDIT3 downstream of JNK in hypoxia-mediated apoptosis and downregulation of the adaptive UPR. Other effectors must be involved, potentially generated via inflammatory (ESM Fig. 14) and/or metabolic pathways. The UPR during hypoxia resembles the beta cell response to low non-stimulatory glucose concentrations where ATP and ER $\left[\mathrm{Ca}^{2+}\right]$ levels and protein synthesis are reduced [43, 48-50]. However, the inhibitory effect of hypoxia on the adaptive UPR is observed even in the presence of low glucose concentrations (not shown) suggesting additional mechanisms. Our studies suggest that $\mathrm{HIF} 1 \alpha$, an important regulator of cell survival and gene expression during hypoxia $[27,28,51]$, is not required for downregulation of the UPR. Finally, by demonstrating that overproduction of the ER chaperone HSPA5 partially protects against hypoxia-induced apoptosis, we provide the first indication that downregulation of the adaptive UPR contributes to hypoxic stress in beta cells, and by extension to beta cell failure in type 2 diabetes.

In conclusion, we have demonstrated for the first time that hypoxia inhibits the adaptive UPR and ER-to-Golgi protein trafficking in beta cells. The decline of the adaptive UPR is associated with increased beta cell death during hypoxia. Hypoxia might therefore contribute to the failure of the adaptive UPR and the progressive loss of functional beta cell mass in type 2 diabetes. The identification of the hypoxia-JNKDDIT3 axis in adaptive UPR failure may help for the development of therapeutic strategies to protect beta cells in type 2 diabetes and after islet transplantation.

Acknowledgements Some of the data were presented as an abstract at the $51^{\text {st }}$ EASD meeting in Stockholm, Sweden, 15-18 September 2015.

Funding This work was supported by a grant from the National Health and Medical Research Council (NHMRC) of Australia (APP1069511 to DRL). DRL is supported by an Australian Research Council (ARC) Future Fellowship. JCJ is Research Director of the Fonds de la Recherche Scientifique-FNRS, Belgium.

Duality of interest The authors declare that there is no duality of interest associated with this manuscript.

Contribution statement MB and DRL conceived and designed experiments, acquired and analysed data and wrote the manuscript. ELM, JYC, JL, PKW, JCJ and JEG designed experiments, acquired and analysed data, and critically reviewed the manuscript. All authors approved the final version of the manuscript. DRL is the guarantor of this work.

\section{References}

1. Bensellam M, Laybutt DR, Jonas JC (2012) The molecular mechanisms of pancreatic beta-cell glucotoxicity: recent findings and future research directions. Mol Cell Endocrinol 364:1-27

2. Jitrapakdee S, Wutthisathapornchai A, Wallace JC, MacDonald MJ (2010) Regulation of insulin secretion: role of mitochondrial signalling. Diabetologia 53:1019-1032 
3. Jonas JC, Sharma A, Hasenkamp W et al (1999) Chronic hyperglycemia triggers loss of pancreatic $\mathrm{b}$ cell differentiation in an animal model of diabetes. J Biol Chem 274:14112-14121

4. Laybutt DR, Sharma A, Sgroi DC, Gaudet J, Bonner-Weir S, Weir GC (2002) Genetic regulation of metabolic pathways in b-cells disrupted by hyperglycemia. J Biol Chem 277:10912-10921

5. Li X, Zhang L, Meshinchi S et al (2006) Islet microvasculature in islet hyperplasia and failure in a model of type 2 diabetes. Diabetes 55:2965-2973

6. Sato Y, Endo H, Okuyama H et al (2011) Cellular hypoxia of pancreatic b-cells due to high levels of oxygen consumption for insulin secretion in vitro. J Biol Chem 286:12524-12532

7. Bensellam M, Duvillie B, Rybachuk G et al (2012) Glucoseinduced $\mathrm{O}_{2}$ consumption activates hypoxia inducible factors 1 and 2 in rat insulin-secreting pancreatic beta-cells. PLoS One 7: e29807

8. Zheng X, Zheng X, Wang X et al (2012) Acute hypoxia induces apoptosis of pancreatic beta-cell by activation of the unfolded protein response and upregulation of CHOP. Cell Death Dis 3:e322

9. Emamaullee JA, Shapiro AM (2007) Factors influencing the loss of beta-cell mass in islet transplantation. Cell Transplant 16:1-8

10. Olsson R, Olerud J, Pettersson U, Carlsson PO (2011) Increased numbers of low-oxygenated pancreatic islets after intraportal islet transplantation. Diabetes 60:2350-2353

11. Scheuner D, Kaufman RJ (2008) The unfolded protein response: a pathway that links insulin demand with b-cell failure and diabetes. Endocr Rev 29:317-333

12. Eizirik DL, Cardozo AK, Cnop M (2008) The role for endoplasmic reticulum stress in diabetes mellitus. Endocr Rev 29:42-61

13. Fonseca SG, Gromada J, Urano F (2011) Endoplasmic reticulum stress and pancreatic beta-cell death. Trends Endocrinol Metab 22: 266-274

14. Chan JY, Luzuriaga J, Bensellam M, Biden TJ, Laybutt DR (2013) Failure of the adaptive unfolded protein response in islets of obese mice is linked with abnormalities in beta-cell gene expression and progression to diabetes. Diabetes 62:1557-1568

15. Omikorede $\mathrm{O}, \mathrm{Qi}$ C, Gorman T et al (2013) ER stress in rodent islets of Langerhans is concomitant with obesity and beta-cell compensation but not with beta-cell dysfunction and diabetes. Nutr Diabetes 3:e93

16. Engin F, Nguyen T, Yermalovich A, Hotamisligil GS (2014) Aberrant islet unfolded protein response in type 2 diabetes. Sci Rep 4:4054

17. Walters SN, Luzuriaga J, Chan JY, Grey ST, Laybutt DR (2013) Influence of chronic hyperglycemia on the loss of the unfolded protein response in transplanted islets. J Mol Endocrinol 51:225232

18. Laybutt DR, Preston AM, Akerfeldt MC et al (2007) Endoplasmic reticulum stress contributes to beta cell apoptosis in type 2 diabetes. Diabetologia 50:752-763

19. Chan JY, Luzuriaga J, Maxwell EL, West PK, Bensellam M, Laybutt DR (2015) The balance between adaptive and apoptotic unfolded protein responses regulates beta-cell death under ER stress conditions through XBP1, CHOP and JNK. Mol Cell Endocrinol 413:189-201

20. Bensellam M, Montgomery MK, Luzuriaga J, Chan JY, Laybutt DR (2015) Inhibitor of differentiation proteins protect against oxidative stress by regulating the antioxidantmitochondrial response in mouse beta cells. Diabetologia 58:758-770

21. Preston AM, Gurisik E, Bartley C, Laybutt DR, Biden TJ (2009) Reduced endoplasmic reticulum (ER)-to-Golgi protein trafficking contributes to ER stress in lipotoxic mouse beta cells by promoting protein overload. Diabetologia 52:2369-2373

22. Boslem E, MacIntosh G, Preston AM et al (2011) A lipidomic screen of palmitate-treated MIN6 beta-cells links sphingolipid metabolites with endoplasmic reticulum (ER) stress and impaired protein trafficking. Biochem J 435:267-276

23. Jonas JC, Bensellam M, Duprez J, Elouil H, Guiot Y, Pascal SM (2009) Glucose regulation of islet stress responses and b-cell failure in type 2 diabetes. Diabetes Obes Metab 11(Suppl 4):S65-S81

24. Shaffer AL, Shapiro-Shelef M, Iwakoshi NN et al (2004) XBP1, downstream of Blimp-1, expands the secretory apparatus and other organelles, and increases protein synthesis in plasma cell differentiation. Immunity 21:81-93

25. Sriburi R, Bommiasamy H, Buldak GL et al (2007) Coordinate regulation of phospholipid biosynthesis and secretory pathway gene expression in XBP-1(S)-induced endoplasmic reticulum biogenesis. J Biol Chem 282:7024-7034

26. Presley JF, Cole NB, Schroer TA, Hirschberg K, Zaal KJ, Lippincott-Schwartz J (1997) ER-to-Golgi transport visualized in living cells. Nature 389:81-85

27. Ivan M, Harris AL, Martelli F, Kulshreshtha R (2008) Hypoxia response and microRNAs: no longer two separate worlds. J Cell Mol Med 12:1426-1431

28. Semenza GL (2012) Hypoxia-inducible factors in physiology and medicine. Cell 148:399-408

29. Abdelli S, Abderrahmani A, Hering BJ, Beckmann JS, Bonny C (2007) The c-Jun N-terminal kinase JNK participates in cytokineand isolation stress-induced rat pancreatic islet apoptosis. Diabetologia 50:1660-1669

30. Abderrahmani A, Niederhauser G, Favre D et al (2007) Human high-density lipoprotein particles prevent activation of the JNK pathway induced by human oxidised low-density lipoprotein particles in pancreatic beta cells. Diabetologia 50:1304-1314

31. Maedler K, Schulthess FT, Bielman C et al (2008) Glucose and leptin induce apoptosis in human beta-cells and impair glucosestimulated insulin secretion through activation of c-Jun N-terminal kinases. FASEB J 22:1905-1913

32. Chan JY, Cooney GJ, Biden TJ, Laybutt DR (2011) Differential regulation of adaptive and apoptotic unfolded protein response signalling by cytokine-induced nitric oxide production in mouse pancreatic beta cells. Diabetologia 54:1766-1776

33. Subramanian SL, Hull RL, Zraika S, Aston-Mourney K, Udayasankar J, Kahn SE (2012) cJUN N-terminal kinase (JNK) activation mediates islet amyloid-induced beta cell apoptosis in cultured human islet amyloid polypeptide transgenic mouse islets. Diabetologia 55:166-174

34. Brozzi F, Nardelli TR, Lopes M et al (2015) Cytokines induce endoplasmic reticulum stress in human, rat and mouse beta cells via different mechanisms. Diabetologia 58:2307-2316

35. Ron D, Habener JF (1992) CHOP, a novel developmentally regulated nuclear protein that dimerizes with transcription factors $\mathrm{C} / \mathrm{EBP}$ and LAP and functions as a dominant-negative inhibitor of gene transcription. Genes Dev 6:439-453

36. Jauhiainen A, Thomsen C, Strombom L et al (2012) Distinct cytoplasmic and nuclear functions of the stress induced protein DDIT3/ CHOP/GADD153. PLoS One 7:e33208

37. Sato Y, Inoue M, Yoshizawa T, Yamagata K (2014) Moderate hypoxia induces beta-cell dysfunction with HIF-1-independent gene expression changes. PLoS One 9:e114868

38. Thuerauf DJ, Marcinko M, Gude N, Rubio M, Sussman MA, Glembotski CC (2006) Activation of the unfolded protein response in infarcted mouse heart and hypoxic cultured cardiac myocytes. Circ Res 99:275-282

39. Koumenis C, Naczki C, Koritzinsky M et al (2002) Regulation of protein synthesis by hypoxia via activation of the endoplasmic reticulum kinase PERK and phosphorylation of the translation initiation factor eIF $2 \alpha$. Mol Cell Biol 22:7405-7416

40. Romero-Ramirez L, Cao H, Nelson D et al (2004) XBP1 is essential for survival under hypoxic conditions and is required for tumor growth. Cancer Res 64:5943-5947 
41. Liu Y, Laszlo C, Liu Y et al (2010) Regulation of G(1) arrest and apoptosis in hypoxia by PERK and GCN2-mediated eIF $2 \alpha$ phosphorylation. Neoplasia 12:61-68

42. Zhu Z, Zhong H, Zhou Q et al (2015) Inhibition of PKR impairs angiogenesis through a VEGF pathway. Am J Physiol Endocrinol Metab 308:E518-E524

43. Bensellam M, Van Lommel L, Overbergh L, Schuit FC, Jonas JC (2009) Cluster analysis of rat pancreatic islet gene mRNA levels after culture in low-, intermediate- and high-glucose concentrations. Diabetologia 52:463-476

44. Norlin S, Parekh VS, Naredi P, Edlund H (2015) Asna1/TRC40 controls beta cell function and ER homeostasis by ensuring retrograde transport. Diabetes 65:110-119

45. Petremand J, Puyal J, Chatton JY et al (2012) HDLs protect pancreatic beta-cells against ER stress by restoring protein folding and trafficking. Diabetes 61:1100-1111

46. Pirot P, Ortis F, Cnop M et al (2007) Transcriptional regulation of the endoplasmic reticulum stress gene chop in pancreatic insulinproducing cells. Diabetes 56:1069-1077
47. Song B, Scheuner D, Ron D, Pennathur S, Kaufman RJ (2008) Chop deletion reduces oxidative stress, improves b cell function, and promotes cell survival in multiple mouse models of diabetes. J Clin Invest 118:3378-3389

48. Elouil H, Bensellam M, Guiot $Y$ et al (2007) Acute nutrient regulation of the unfolded protein response and integrated stress response in cultured rat pancreatic islets. Diabetologia 50:14421452

49. Gomez E, Powell ML, Bevington A, Herbert TP (2008) A decrease in cellular energy status stimulates PERK-dependent eIF $2 \alpha$ phosphorylation and regulates protein synthesis in pancreatic beta-cells. Biochem J 410:485-493

50. Moore CE, Omikorede O, Gomez E, Willars GB, Herbert TP (2011) PERK activation at low glucose concentration is mediated by SERCA pump inhibition and confers preemptive cytoprotection to pancreatic b-cells. Mol Endocrinol 25:315-326

51. Stokes RA, Cheng K, Deters N et al (2013) Hypoxia-inducible factor-1alpha (HIF-1alpha) potentiates beta-cell survival after islet transplantation of human and mouse islets. Cell Transplant 22:253-266 